\title{
Capacity Utilisation in the Large-Scale Manufacturing Sector: An Empirical Analysis
}

\author{
Rukhsana Kalim*
}

\begin{abstract}
This paper is concerned with the quantification of the rate of capacity utilisation and its major determinants in the large-scale manufacturing sector of Pakistan. A cross-section analysis has been made for 68 five digit industries for the period 1995-96. A number of hypothesis have been tested using the regression technique. Keeping in view the problem of load shedding in Pakistan, it has been taken as an important variable affecting the rate of capacity utilisation in the manufacturing sector. Regression results are in conformity with the earlier studies that supply factors are playing a major role in determining the rate of capacity utilisation. Among supply factors electricity consumption has appeared to be statistically significant.
\end{abstract}

\section{Introduction}

An important factor determining industrial output employment and employment is the maximum utilisation of the existing stock of capital in developing countries. These countries are generally characterised with a scarcity of capital stock on the one hand and underutilisation of the capital stock on the other. Pakistan also faces a similar perplexed situation as the average rate of capacity utilisation in the manufacturing sector is very low. For example, Farooq and Winston (1978) cited in their studies that industrial capital stocks in both Pakistan and Korea are idle over 85 per cent of the time (p. 227). Similarly, Hogan (1967), Winston (1971), Kemal and Allauddin (1974), and Pasha and Qureshi (1984) have also reported a low rate of capacity utilisation in the manufacturing sector of Pakistan. Hence, the detailed analysis of the low rate of capacity utilisation in the manufacturing sector of Pakistan is self evident.

A number of factors are considered responsible for the low rate of capacity utilisation. However, with reference to Pakistan one could argue that since 1980 there has been widespread load shedding across the country. The problem of irregular supply of electricity accentuates particularly during the summer. This may have affected the rate of capacity utilisation in the large scale manufacturing sector of Pakistan. Contrary to the earlier studies this

*Assistant Professor of Economics at the Fatima Jinnah Women University, Rawalpindi. 
paper explicitly takes into account load shedding/irregular electricity supply (which is proxied by electricity consumption) as an important variable affecting the rate of capacity utilisation in the manufacturing sector of Pakistan.

The organisation of the paper is as follows: Section-II describes methodology and data description. In Section-III the existing rate of capacity utilisation in the manufacturing sector is calculated. Section-IV develops a model of capacity utilisation followed by testing different determinants of the rate of capacity utilisation. Section-V discusses regression results. Finally Section-VI concludes with some major findings.

\section{Methodology and Data Description}

For the analysis of capacity utilisation 68 industries at the five digit level of Pakistan Standard Industrial Classifications were selected. These industries account for 82 per cent of total value added of large-scale industries. Cross-sectional data for the year 1995-96 has been utilised. For estimation purposes the OLS technique has been used. The source of data is the CMI (1995-96) and Pakistan Statistical Year Book (1998). The data on capacity utilisation has been calculated by using a formula (which will be given in Section-III). The quality of data is always a problem in developing countries, increasing the likelihood of measurement error in regression analysis and Pakistan is no exception to this. As a rule of thumb if the rate of capacity utilisation is below 50 per cent, we could say that the rate of capacity utilisation is low in the large-scale manufacturing sector.

\section{The Rate of Capacity Utilisation}

Although economic literature provides many ways to measure the rate of capacity utilisation (see Leeuw 1962; Schultz 1963; Winston 1974a, b; Betancourt and Clague 1975), however, Lim (1976) recommends a time measure, Ut, as a more reliable measure of capacity utilisation. In this method, the rate of capacity utilisation is expressed as the ratio of actual number of working hours of a plant to total number of working hours available in a year. The technique has one drawback in that it does not make any allowance for maintenance and repair of plants and machinery. A refinement to the Ut measure is the inclusion of an intensity measure Uit, which takes into account the intensity of the operation of the plant. For example, if the entrepreneur intends to run the plant at 100 per cent of Ut, there would not be any difference between the Ut and Uit measures. However, if the entrepreneur's intention is to run the plant by only 50 per cent Ut would be adjusted downward by half. 
As no substantial difference in the rates of capacity utilisation based on Ut and Uit measures has been found by Lim (1976), Ut is still said to be a good approximation of capacity utilisation. We have used the time measure Ut of estimating the rate of capacity utilisation in Pakistan's manufacturing sector by making an allowance for the maintenance and repair of plant and machinery. The technique has been selected mainly because of its simplicity. This method can be simply written as:

$$
\begin{aligned}
\mathrm{Ut}= & \text { DW.HW.SW } \\
& \text { DA.HA.SA }
\end{aligned}
$$

Where;

DW = Actual days worked per year by the firm

$\mathrm{HW}=$ Actual hours worked per shift by the firm

$\mathrm{SW}=$ Actual number of shifts operated by the firm

$\mathrm{DA}=$ Potential days available per year

$\mathrm{HA}=$ Potential hours per shift assumed

$\mathrm{SA}=$ Potential number of shifts per day

For the potential values in the denominator we have assumed total number of potential working days per year 300; number of potential working hours in each shift 8; and finally the maximum shift coefficient/ number of shifts per day 3 . An allowance of 65 days per year has been made for the maintenance of plant and machinery. Thus, the maximum capacity utilisation from our point of view is the level of output which firms achieve if they were working at 7200 total hours per year. In other words, capacity utilisation can be expressed as:-

$$
\mathrm{Ut}=\begin{aligned}
& \mathrm{DW} \cdot \mathrm{HW} \cdot \mathrm{SW} \\
& 300.8 .3
\end{aligned}
$$

In the above formulation, variables that affect the rate of capacity utilisation are the number of days worked per year, hours worked per shift, and the number of shifts per day. The assumption of 3 shifts may not be realised in practice for many types of industries. For some industries such as chemicals, cement, mineral processing, and fertilisers which are continuous process industries, the assumption of three shifts may hold true. However, there are non-continuous process or batch making industries. Generally these industries produce several types of products in batches, operating generally in only one shift. However, some units may produce one type of product in several sizes in one or two shifts, and a very small number operate three shifts. As the above formula is a theoretical measure of a plant's maximum capability, by definition, the 
capacity measure would be uniform for both continuous and noncontinuous or batch process industries. According to Winston (1971) there is a wide variety in the number of shifts a firm considers normal, and therefore the level of operation it reports to any data-collecting agency as "full utilisation" of capacity (p. 41). Hence, it makes sense to accept selfimposed, subjective standards of full utilisation and ask whether performance measures up to them (Winston 1971, p 42). It is quite possible that the standard maximum working hours may conflict with the entrepreneurial standards of correct capital use. However, owing to the scarcity of capital in developing countries, the firm's idea of full utilisation of capital is generally disregarded and it is assumed that utilisation of the existing stock of capital through an increased total number of working hours/shift work is possible and relatively costless (see Winston, 1971 for theoretical discussion).

The criteria for selecting industries is based on total demand for the product of each industry. Consideration of the demand element is important because demand constraints may be a major obstacle to full utilisation of capital stock in most industries. We have selected those industries where exports or imports are at least 10 per cent of their total output. The implicit assumption behind this is that these firms have no shortfall of demand. But in some industries even without significant exports or imports there may not be any demand constraint. For example, we have noticed that in the vegetable ghee, starch, fertilizer, and cement industries the number of working days per year are more than our assumed number. Hence these industries may have sufficient domestic demand without having 10 per cent exports or imports. Another possibility is that these industries may be carrying out maintenance during the day rather than having to close the factory down.

Some provision is also made for seasonal industries. For the sugar industry, because of its seasonal nature, i.e., not working the full year, we have assumed 6000 as the maximum total working hours during a year.

The details of capacity utilisation pattern in 68 industries is provided in Table- 1 which shows that capacity utilisation ranges from very low 24 per cent to very high 115 per cent. The average rate of capacity utilisation is 45 per cent per annum. However, average capacity utilisation is slightly more than 60 per cent when weighted either by the value of fixed assets or by value added. Industries where capacity utilisation is very high are vegetable ghee, starch, cotton spinning, alkalies, glass, fertilizers, and cement. Only 16 industries out of a total 68 industries show capacity utilisation above average while the remaining 52 industries work below average (Table-1). 
Table-1: Average Rate of Capacity Utilisation

\begin{tabular}{|c|c|c|}
\hline \multicolumn{2}{|r|}{ Industries } & \multirow{2}{*}{$\frac{\text { Capacity Utilisation }}{0.36}$} \\
\hline 1. & Canning of fruits and vegetables & \\
\hline 2 . & Canning of fish and sea food & 0.29 \\
\hline 3. & Vegetable ghee & 1.06 \\
\hline 4. & Other vegetable oils & 0.60 \\
\hline 5 . & Sugar & 0.55 \\
\hline 6. & Feeds for animal & 0.24 \\
\hline 7. & Starch & 1.01 \\
\hline 8 . & Salt & 0.34 \\
\hline 9 . & Spirits \& wine and fruit products & 0.35 \\
\hline 10. & Other Soft Drinks & 0.35 \\
\hline 11. & Cigarettes & 0.64 \\
\hline 12. & Cotton spinning & 1.03 \\
\hline 13. & Woollen textiles & 0.45 \\
\hline 14. & Silk and art silk textiles & 0.58 \\
\hline 15 . & Finishing of textiles & 0.35 \\
\hline 16 . & Made up textile goods & 0.42 \\
\hline 17. & Carpets and rug cotton & 0.20 \\
\hline 18. & Carpets and rugs Woollen & 0.32 \\
\hline 19. & Spooling and thread ball making & 0.35 \\
\hline 20. & Other textiles & 0.45 \\
\hline 21. & Tanning and leather finishing & 0.30 \\
\hline 22. & Other leather products & 0.42 \\
\hline 23. & Plywood and products & 0.30 \\
\hline 24 . & Medicines and drugs & 0.31 \\
\hline 25 . & Unani and other medicines & 0.30 \\
\hline 26. & Alkalies & 1.00 \\
\hline
\end{tabular}


148 The Lahore Journal of Economics, Vol.6, No.1

\begin{tabular}{|c|c|c|}
\hline & Industries & Capacity Utilisation \\
\hline 27. & Acids, salts and intermediates & 0.50 \\
\hline 28. & Dyes, colours and pigments & 0.51 \\
\hline 29. & Fertilizers & 1.10 \\
\hline 30. & Paints, varnishes and lacquers & 0.40 \\
\hline 31. & Perfumes and cosmetics & 0.30 \\
\hline 32. & Soap and detergent & 0.42 \\
\hline 33. & Matches & 0.56 \\
\hline 34. & Petroleum products & 0.40 \\
\hline 35 . & Tyres and tubes & 0.48 \\
\hline 36. & Retreading tyres and tubes & 0.35 \\
\hline 37. & Rubber foot-wear & 0.32 \\
\hline 38. & Glass & 1.04 \\
\hline 39. & Glass products & 0.56 \\
\hline 40. & Bricks and tiles & 0.35 \\
\hline 41. & Cement & 1.15 \\
\hline 42. & Cement products & 0.35 \\
\hline 43. & Other non-metallic mineral products & 0.36 \\
\hline 44. & Iron and steel mills & 0.47 \\
\hline 45 . & Iron and steel foundries basic industries & 0.45 \\
\hline 46. & Re-rolling mills & 0.35 \\
\hline 47. & Cutlery & 0.34 \\
\hline 48. & Metal furniture & 0.36 \\
\hline 49. & Wire product & 0.40 \\
\hline 50. & Metals barrels and drums & 0.33 \\
\hline 51. & Bolts, nuts, rivets etc. & 0.33 \\
\hline 52. & Engines and turbines & 0.34 \\
\hline 53. & Agricultural machinery & 0.36 \\
\hline
\end{tabular}

Cont. 


\begin{tabular}{clc}
\hline & \multicolumn{1}{c}{ Industries } & Capacity Utilisation \\
\hline 54. & Textile machinery & 0.36 \\
55. & Other industrial machinery & 0.37 \\
56. & Electrical industrial machinery & 0.34 \\
57. & Radio and television & 0.30 \\
58. & Electrical appliances & 0.29 \\
59. & Insulated wires and cables & 0.40 \\
60. & Ship and boat building & 0.37 \\
61. & Rail road equipment & 0.32 \\
62. & Motor vehicles & 0.36 \\
63. & Motor Cycles, auto rickshaws & 0.35 \\
64. & Cycles and pedicabs & 0.36 \\
65. & Jewellery and musical instruments & 0.31 \\
66. & Toys & 0.47 \\
67. & Pens and office supplies & 0.30 \\
68. & Other manufacturing & 0.32 \\
\hline
\end{tabular}

\begin{tabular}{|c|c|}
\hline $\begin{array}{l}\text { Simple Average } \\
\text { Weighted Average }\end{array}$ & 0.45 \\
\hline $\begin{array}{l}\text { (weighted by the } \\
\text { value of fixed assets) }\end{array}$ & 0.65 \\
\hline $\begin{array}{l}\text { Weighted Average } \\
\text { (weighted by value added) }\end{array}$ & 0.64 \\
\hline
\end{tabular}

It is very clear from Table-1 that more than 50 per cent of the industrial capacity was lying idle in 1995-96 and there are large interindustry variations in capacity utilisation.

The correlation coefficient between capacity utilisation and the average number of shifts in our analysis is 0.99 which is positive and very high. This implies that any increase in the number of shifts would be a means of increasing capacity utilisation in the manufacturing sector of Pakistan. 
150 The Lahore Journal of Economics, Vol.6, No.1

\section{A Model of Capacity Utilisation in Pakistan}

Our model of capacity utilisation in Pakistan attempts to estimate a multiple regression equation (explaining inter-industry differences in capacity utilisation) using cross-sectional data for 68 industrial groups for the year 1995-96. The main question under consideration is why the existing stock of capital is not fully utilised in Pakistan's manufacturing sector. The model to test the various hypotheses concerning factors affecting capacity utilisation is specified in the following form;

$$
\text { Cui }=\mathrm{a} 1+\mathrm{b} 1 \mathrm{xli}+\mathrm{b} 2 \times 2 \mathrm{i} \ldots \text { bnxni }+\mathrm{ui}(1)
$$

Where Cui is a capacity utilisation in industry $i$ and xli $x 2 i$..xni are the explanatory variables for industry $i$. ui is the error term.

\section{Hypotheses and Variables}

The following are the variables included in the model:

Electricity Shortage (lel): In our opinion an important factor affecting capacity utilisation in Pakistan's manufacturing sector may be the irregular power supply/load-shedding. Owing to the increased demand for electricity, the government has used a load-shedding programme since the 1980s. Industries may be reluctant to increase total working hours in view of the possibility of power shut down at different periods of time.

The seriousness of electricity shortage may also be observed by a WAPDA press release. During 1990-91, industrial units were advised to reduce the use of electricity from $5 \mathrm{pm}$ to $8 \mathrm{pm}$. This timing was selected because of the increased demand for electricity at this time of day. The main points are stated below:-

All steel furnaces which get electricity from separate feeders, the supply of electricity to them is shut down from 5 to 8 p.m.

All steel and re-rolling mills which are supplied from mixed feeders, the supply of electricity will shut down from 5 to 8 p.m.

All textile mills are directed to reduce the consumption of electricity voluntarily between 5 to 8 p.m. If they do not, WAPDA will be forced to stop supplying electricity.

Continuous process industries such as cement, chemical plant, medicine making units, fine paper, glass, and pottery etc. which get 
electricity from feeders separate from WAPDA, are advised to cut down the electricity load by $25 \%$ between 5 to 8 p.m.

Comparatively less important industries, i.e. industries which work in one or two shifts, will be closed between 5 to 8 p.m.

Although the above WAPDA statement was released during the early period of the 1990s, the problem still remains intact. Load shedding is likely to continue especially in summer and even to increase in the future. It has been forecast that by the year 2010 the country will require the generation of more than 34,191 MW electricity and installed capacity will not be higher than $19,000 \mathrm{MW}$. Thus Pakistan is likely to face an energy shortage in the future.

UNIDO (1990) has referred to a study report by the United States Agency for International Development (USAID), according to which Pakistan is losing about $\$ 500$ million annually of value added in manufacturing due to load-shedding (p. 90). It has also been reported that hydro-season induced load-shedding results in an 18 per cent loss of manufacturing value added for small industries, compared with 5.5 per cent for large industries (UNIDO, 1990, p. 90). Pasha and Qureshi (1984) have also reported that the percentage of days to total days lost due to power failure was the highest (27\%) during 1971-76 (p. 41).

The data shows that the consumption of electricity by the industrial sector has declined from 1029.16 TOE to 975, 788 TOE in 1993-94 and 1996-97 respectively (Pakistan Energy Year Book, 1999). This might be due to the power breakdown and irregular supply of electricity to the industries. The escalation of electricity tariffs might be an additional reason for the decline in the consumption of electricity.

On the basis of all this information we hypothesise that power shortage/breakdowns may be an important factor hindering capacity utilisation and introducing more shifts into the system. The major difficulty that we face is the lack of data on the actual and desired consumption of electricity in industries to substantiate the effect of shortage of electricity on capacity utilisation. To get round the problem the electricity consumption as a proportion of value added is proxied for load shedding on the basis of the assumption that there is a functional relationship between output and electricity consumption on the one hand and capacity utilisation and electricity consumption on the other. We assume that output is a function of electricity consumption. (See appendix for the statistical relationship). As the former is also a function of capacity utilisation a positive relationship may be postulated between capacity utilisation and electricity consumption as well. 
Our hypothesised positive relationship between electricity consumption and capacity utilisation in fact stems from some other studies where the consumption of electricity has been proxied to measure capacity utilisation in industries. For example, Kim and Kwon (1971) used electricity consumption as a measure of capacity utilisation. Hence, after establishing this positive relationship in the manufacturing sector of Pakistan we implicitly assume that as power is shut down, consumption of electricity is disrupted in industries, thus both output and capacity utilisation may be affected. However, the limitation of this assumption is that if firms get electricity supply from some other sources e.g., they use their generators etc., output and capacity utilisation may not be affected much.

Exports/Demand Pressure (lexp/lag): A positive relationship is hypothesised between exports and capacity utilisation. It is generally expected that higher exports would enable a firm to utilise more of its production capacity because of higher demand for the product. The proportion of exports to total output (lexp) has been taken to reflect demand for the product. Alternatively we have also tested total demand pressure on an industry with the assumption that higher demand for a product would lead to more capacity utilisation and vice versa. Following Goldar and Renganathan (1991) we have taken the annual average growth rate of production between 1977-78 and 1984-85 (lag) in each industry to reflect total demand pressure on industries.

Imported Raw Material (lim): This variable is taken as the ratio of imported raw material to total inputs and reflects industry's dependence on imported raw materials. An inverse relationship is expected to prevail between capacity utilisation and imported raw-materials. The logic behind this negative relation is that the difficulties in getting foreign exchange or import licences in time create problems for the availability of raw materials and reduce capacity utilisation.

Average size of the firm (1s): This variable can be measured either in terms of value of fixed assets per firm or total employment per firm. We have used both of these measures. A positive relationship between capital utilisation and size of the firm is hypothesised. Larger firms are more capable of maintaining a high level of capacity utilisation and vice versa.

Number of firms (ln): The number of units in the industry is taken as a proxy for the extent of competition or market structure within the industry. It is positively related to capacity utilisation. The assumption is that the more the number of firms, the greater will be the degree of competition and hence, more inducement to utilise the stock of capital. 
Labour Productivity (1vl): This is taken in terms of total value added per employee. A positive relationship is assumed to prevail between labour productivity and capacity utilisation.

Capital-value added ratio $(K / V)$ : This variable is the ratio of fixed assets to value-added by industry. It corresponds to the capital-output ratio for a firm. A different type of relationship between the capital-output ratio and the rate of capacity utilisation has been given by Malcolmson (1973). It is emphasised that capital-intensive undertakings are characterised more by plant indivisibilities, implying concave costs of adjustment of capacity. In such cases there will be a greater tendency to create capacity ahead of demand. This implies that, in the initial years of a plant's life, there may be some built-in excess capacity. The other reason is that capital-intensive investment frequently embodies the transfer of complex technology, and it takes a longer time for management in developing countries to master the operations of such plants. These arguments imply a negative relation between the capital-output ratio and capacity utilisation.

\section{Results}

Our model has two sets of data. The first set takes the average size of the firm in terms of total employment per firm (1s). The second set measures the average size of the firm in terms of total value of fixed assets per firm (1sa). We have checked all our estimates for the presence of heteroscedasticity by applying different tests but found no element of heteroscedasticity.

Initially we have tested our model by taking into account all variables in the model. Four variables out of the seven are insignificant and do not seem to have any impact on capacity utilisation. These are number of firms (1n), capital value added ratio (1k/v), exports (1exp) and imported raw material (lim). On the other hand average size of the firm (1s), labour productivity (1v/1) and electricity (1e1) are highly significant at the 1 per cent level. All the significant variables have the correct expected signs. The $R^{2}$ is 0.60 (Table-2).

We have also measured total demand pressure in industry by taking average growth rate of output between 1984-85 - 1995-96 (lag) and tested the model by using the first set of data. The average growth rate (lag) is insignificant and overall statistical results are not different from the earlier ones (see Table-3). 
154 The Lahore Journal of Economics, Vol.6, No.1

Table-2: Regression Results (First set of data)

\begin{tabular}{lccl}
\hline Variable & Estimated coefficient & t-ratio & \\
\hline $1 \mathrm{n}$ & -0.132 & -0.314 & $\mathrm{R}^{2}=0.60$ \\
$1 \mathrm{~s}$ & 0.156 & $4.875^{*}$ & $\mathrm{R}=0.55$ \\
$\mathrm{1v} 1$ & 0.167 & $3.103^{*}$ & \\
$1 \mathrm{e} 1$ & 0.232 & $5.467^{*}$ & $\mathrm{~F}(8 \quad 60)=11.915$ \\
$1 \mathrm{kv}$ & -0.073 & -1.301 & \\
$\operatorname{lexp}$ & 0.021 & 1.187 & \\
$\lim$ & 0.016 & 0.643 & \\
cons & -1.683 & -7.564 & \\
\hline
\end{tabular}

* significant at the $1 \%$ level.

Table-3: Regression Results (First set of data)

\begin{tabular}{lccl}
\hline Variable & Estimated coefficient & T-ratio & \\
\hline $1 \mathrm{n}$ & -0.017 & -0.573 & $\mathrm{R}^{2}=0.73$ \\
$1 \mathrm{~s}$ & 0.976 & $2.670^{*}$ & $\mathrm{R}=0.69$ \\
$\mathrm{1v} 1$ & 0.172 & $3.108^{*}$ & \\
$1 \mathrm{e} 1$ & 0.203 & $4.951^{*}$ & $\mathrm{~F}(8 \quad 60)=17.712$ \\
$1 \mathrm{kv}$ & -0.051 & -0.895 & \\
$\mathrm{1ag}$ & -0.005 & -0.216 & \\
$\lim$ & 0.028 & 0.251 & \\
cons & -1.932 & -1.232 & \\
\hline
\end{tabular}

* significant at the $1 \%$ level.

In the second set of data, labour productivity (1v1) has become insignificant along with number of firms (1n), exports (lexp), and imported raw material $(\mathrm{lim})$ while capital value added ratio $(1 \mathrm{kv})$ is significant at the $1 \%$ level (Table-4). The correlation coefficient between $1 \mathrm{kv}$ and $1 \mathrm{vl}$ is 0.654 implying multicollinearity between capital value added ratio and labour productivity. This may be one of the reasons for an insignificant effect of labour productivity on capacity utilisation. 
Table-4: Regression Results (Second set of data)

\begin{tabular}{lccl}
\hline Variable & Estimated coefficient & t-ratio & \\
\hline $\ln$ & -0.098 & -0.298 & $\mathrm{R}^{2}=0.58$ \\
$1 \mathrm{sa}$ & 0.131 & $4.124^{*}$ & $\mathrm{R}=0.50$ \\
$\mathrm{kv} 1$ & 0.085 & 0.873 & \\
$1 \mathrm{e} 1$ & 0.230 & $5.517^{*}$ & $\mathrm{~F}(8 \quad 60)=9.998$ \\
$1 \mathrm{kv}$ & -0.158 & $-2.315^{*}$ & \\
$\operatorname{lexp}$ & 0.029 & 0.096 & \\
$\lim$ & 0.023 & 0.646 & \\
cons & -1.763 & -7.126 & \\
\hline
\end{tabular}

* significant at the $1 \%$ level.

Finally, dropping all insignificant variables we have reported our final results by using both sets of data (Tables-5 and 6).

Table-5: Final Regression Results (First set of data)

\begin{tabular}{lccl}
\hline Variables & Coefficients & t-ratio & \\
\hline 1s & 0.139 & $4.686^{*}$ & $\mathrm{R}^{2}=0.56$ \\
1v1 & 0.188 & $3.928^{*}$ & $\mathrm{R}=0.53$ \\
1e1 & 0.199 & $5.787^{*}$ & $\mathrm{~F}(463)=26.66$ \\
Constant & -1.931 & -9.796 & \\
\hline
\end{tabular}

* $1 \%$ level of significance.

Our final results show all the three variables viz; average size of the firm (1s), labour productivity (1v1) and electricity consumption (1el) are highly significant at the $1 \%$ level (Table-5). The value of $\mathrm{R}^{2}$ indicates that 56 per cent of the variation of dependent variable is explained by the independent variables. The value of $\mathrm{F}$ test shows that the model is well specified.

The regression results using the second set of data are reported in Table-6. In this mode1 all variables viz: average size of firm (1sa), electricity consumption (1el) and capital value added ratio (1kv) are significant at the $1 \%$ level. There is a negative relationship between capital value added ratios and capacity utilisation. The $\mathrm{F}$ test shows that the overall fit is good. The value 
156 The Lahore Journal of Economics, Vol.6, No.1

of $\mathrm{R}^{2}$ shows that 54 per cent changes in capacity utilisation are explained by average size of firm, electricity consumption and capital-value added ratio.

Table-6: Final Regression Results (Second set of data)

\begin{tabular}{lccl}
\hline Variables & Coefficients & t-ratio & \\
\hline $1 \mathrm{sa}$ & 0.152 & $6.728^{*}$ & $\mathrm{R}^{2}=0.54$ \\
$1 \mathrm{e} 1$ & 0.237 & $5.574^{*}$ & $\mathrm{R}=0.52$ \\
$\mathrm{1kv}$ & -0.214 & $-3.837^{*}$ & $\mathrm{~F}(463)=23.135$ \\
Constant & -1.730 & -8.940 & \\
\hline
\end{tabular}

* $1 \%$ level of significance.

The number of firms (1n) appears insignificant, implying that market structure does not affect capacity utilisation in the manufacturing sector of Pakistan. A similar result has been found by Kemal and Aluaddin (1974) and Pasha and Qureshi (1984) in their empirical studies. Winston (1971) however, reported the number of firms significant at the 95 per cent level of confidence (see p. 47).

Imported raw materials also appear insignificant in our statistical results. However, earlier Winston (1971), reported the significance of imported raw material at the 99 per cent level of confidence for the year 1965-66. During the sixties, the import policy of Pakistan was highly restricted and licenses were issued for imports of raw materials and machinery. But gradual liberalisation of imports may have reduced the significance of this variable. Many industries such as transport, drugs and pharmaceuticals, agricultural machinery, industrial machinery, steel, motor vehicles such as the car industry etc. still depend on imported raw materials (CMI, 1995-96), but because of a more liberal import policy it may no longer be a hindrance to capacity utilisation.

The size of firm measured either in terms of employment or value of fixed assets is highly significant at the 1 per cent level (Tables-5 and 6). There is also no significant difference in the coefficient of average size of firms in terms of two measures (Tables-5 and 6). Thus, other things being equal, larger units have higher rates of capacity utilisation. Our result is in conformity with the results of Pasha and Qureshi (1984) who quoted the significance of average size of firm at the 5 per cent level (see p. 48). Islam (1978), also provides similar evidence for the manufacturing sector of Bangladesh. 
The electricity variable is significant at the 1 per cent level. The sign of the coefficient is consistent with our expectations. The magnitude of the coefficient shows that a 1 per cent change in electricity consumption will bring about a 0.20 per cent change in capacity utilisation. Given the positive and strong relationship between electricity consumption and capacity utilisation, we may say that any uncertainty in power supply may affect further utilisation of idle capacity.

Labour productivity (1v1) is significant at the 1 per cent level (Table6). There may be many explanations for the positive relationship between capacity utilisation and labour productivity. If high labour productivity reflects high capital intensity then it may be said that capital intensive firms have a high rate of capacity utilisation. However, in our regression analysis a negative relationship has been found between capital-value added ratios and capacity utilisation and a contradiction exists in capital intensity in terms of high labour productivity and high capital-value added ratios. One plausible reason may be that the functional relationship among different variables under production function analysis are based on many stringent assumptions which in reality may be difficult to sustain. High labour productivity may be reflecting economies of scale and efficiency of firms and these firms may have a greater tendency to utilise their capacity.

The capital-value added ratio is also significant at the 1 per cent level. The negative relationship between the capital-value added ratio (1kv) and capital utilisation confirms Malcolmson's (1973) type of argument that capital-intensive plants may have a tendency to remain idle for most of the time due to indivisibility of the plant.

\section{Conclusion}

Our analysis has shown that on average the rate of capacity utilisation is very low and a sizeable capacity lies idle in the manufacturing sector of Pakistan. However, a margin of error always remains in statistical analysis and results should be interpreted with caution. A number of factors have been tested determining the rate of capacity utilisation. Regression results show that the consumption of electricity, labour productivity, average size of firm and the capital-value added ratio are the major factors affecting the rate of capacity utilisation in industries. The nature of these factors is domestic and a prudent policy may be helpful in increasing the rate of capacity utilisation in the industrial sector of Pakistan. 
158 The Lahore Journal of Economics, Vol.6, No.1

\section{Appendix}

\section{Statistical Relationship Between Electricity Consumption and Output}

We have run a regression to quantify the functional relationship between output and electricity consumption in both linear and $\log$ linear form for 68 industries (Table-1) for the year 1995-96. The statistical results are as follows:

$$
\begin{aligned}
& \mathrm{Q}=\underset{(2.878)}{191.58}+\underset{(4.432)^{*}}{2.984 \mathrm{Ele}} \\
& \mathrm{R}^{2}=0.23 \quad \mathrm{~F}=19.637
\end{aligned}
$$

Where $Q$ is value added at constant factor prices of 1975-76, Ele is the consumption of electricity by different industries.

$$
\begin{array}{rll}
\log Q= & \begin{array}{l}
2.913+ \\
(16.750)
\end{array} & \begin{array}{l}
0.735 \text { logele } \\
(11.152)^{*}
\end{array} \\
R^{2} & =0.65 & F=124.363
\end{array}
$$

Where $Q$ is value added at constant factor prices of 1975-76, and ele is the consumption of electricity. Both values are in $\log$ terms. The statistical results show a positive and highly significant relationship between output and electricity consumption in industries at the 99 per cent level of confidence. The coefficient of $\log$ shows that a 1 per cent increase in electricity consumption is associated with a 0.7 per cent increase in output. It means that for any given increase in output a more than proportional increase in consumption of electricity is required. This implies that more generation of electricity would be required to produce more output. 


\section{References}

Farooq, G.M. and G.C. Winston, 1978, "Shift Working, Employment and Economic Development - A Study of Industrial Workers in Pakistan”, Economic Development and Cultural Change, Vol. 26, No. 2, pp. 227-45.

Federal Bureau of Statistics, 2000, “Census of Manufacturing Industries, 1995-96", Unpublished data, Karachi.

Hogan, W.P., 1967, "Capacity Creation and Utilisation in Pakistan Manufacturing Industry” Economic Development Report, September, No. 84, Development Advisory Service, Centre for International Affairs, Harvard University, Cambridge, Mass.

Islam, R., 1978, "Reasons for Idle Capital: The case of Bangladesh Manufacturing”, The Bangladesh Studies, Vo1. VI, Winter, No. 1, pp. 27-51.

Kema1, A.R. and T. Allaudin, 1974, "Capacity Utilisation in Manufacturing Industries of Pakistan”, Pakistan Development Review, Vol. VIII, No.3, pp. 231-44.

Kim, Y.C. and J.K. Kwon, 1971, "A Study on the Level, Trend and Structure of Capital Utilisation in Manufacturing in Korea, 19621970", Northern Illinois University, Illinois.

Lim, D., 1976, "On the Measurement of Capital Utilisation in Less Developed Countries”, Oxford Economic Papers, Vol. 28, No. 28, pp. 149-159.

Malcolmson, J.M., 1973, "Capital Utilisation, the user Cost of Capital and the Cost of adjustment”, International Economic Review, Vol. 16, pp. 173-78.

Ministry of Petroleum and Natural Resources, 1999, “Energy Year Book 1999", Islamabad.

Pasha, H.A. and T. Qureshi, 1984, "Capacity Utilisation in Selected Industries of Pakistan”, Pakistan Journal of Applied Economics, Vol. 111, No. 1, pp. 29-56. 
160 The Lahore Journal of Economics, Vol.6, No.1

UNIDO, 1990, "Pakistan Towards Industrial Liberalization and Revitalization”, Basil Blackwe1l, Oxford Cambridge.

Water and Power Development Authority (WAPDA), 1991, “Press Release 1999", Lahore.

Winston, G.C., 1971, "Capital Utilisation in Economic Development", Economic Journal, Vo1. 81, pp. 36-60. 